\title{
Wine Marketing: Consumer Persuasion through the Region of Origin
}

\author{
Sabrina Latusi ${ }^{1}$, Cristina Zerbini ${ }^{1}$, Silvia Maestripieri ${ }^{1} \&$ Beatrice Luceri ${ }^{1}$ \\ ${ }^{1}$ Department of Economics and Management, University of Parma, Italy \\ Correspondence: Sabrina Latusi, Departement of Economics and Management, University of Parma, Italy. \\ E-mail: sabrina.latusi@unipr.it
}

Received: February 14, 2018

doi:10.5539/ijbm.v13n7p137
Accepted: May 9, 2018

Online Published: June 15, 2018

URL: https://doi.org/10.5539/ijbm.v13n7p137

\begin{abstract}
This study aims to examine the effectiveness of the communication of the region of origin - through either pictorial or pictorial-textual formats - in print advertising messages for wine bearing a GI label. An experimental design was used to manipulate the region of origin presentation in print advertisement (absent vs pictorial vs pictorial-textual) while measuring participants' attitude towards advertisement and purchase intention (dependent variables). Results provide empirical support to the appropriateness of highlighting the geographical area, by combining textual-pictorial cues, to induce a positive attitude towards advertisement and purchase intention in wine consumers. The study makes a new theoretical contribution in the field of communication about wine bearing a GI label, since the persuasive effect of the geographical area has not been systematically tested in an advertising context. Although the wine's place of origin is its signature to many consumers, there is no strong evidence on the effectiveness of conveying the values of such a place through its picture and/or name. For marketing practitioners, the study highlights the opportunity to use extrinsic advertising cues that leverage intangible wine values combining pictorial-textual formats.
\end{abstract}

Keywords: attitude towards the advertisement, purchase intention, geographical indications, print advertising, p-textual cues

\section{Introduction}

The link between a geographical area and a food product has different meanings for consumers. It can evoke authenticity, tradition (Ilbery \& Kneafsey, 1998), the sense of nostalgia for past times in contemporary society (Gilg \& Battershill, 1998) and it can stand for health and safety (Kim, 2008; Mørkbak, Christensen, \& Gyrd-Hansen, 2010). All these denotations create a unique identity for food products (van Ittersum, Candel, \& Meulenberg, 2003), contributing to reducing risk perception in food consumption, as they overcome consumers' concerns on where products come from and how they have been produced.

Given the importance of the role played by the geographical area, wine producing countries issued various regulations concerning the production and the certification of origin (Balestrini \& Gamble, 2006; Anna Guidry, Babin, Graziano, \& Joel Schneider, 2009). For example, the European Union introduced Geographical Indications (GIs) to protect the quality and image of wines from traditional producing areas (Anna Guidry et al., 2009; Luceri, Latusi, \& Zerbini, 2016). GIs connect the characteristics of the product (quality, reputation, etc.) to the place of origin through the specification of traditional methods of production and/or local raw ingredients. They act as a regulated extrinsic quality cue (Dimara \& Skuras, 2003), supporting product differentiation on a regional basis. In sum, the aim of the European GI scheme is to offer strategic opportunities to local productive systems with a strong cultural and natural heritage associated with product quality attributes (Boyazoglu, 1999; Türkekul, Günden, Abay, \& Miran, 2010; Sanz-Cañada \& Muchnik, 2011). These regulations partially explain the difference between the "Old World" and the "New World", widely recognized in the literature (Balestrini \& Gamble, 2006; Anna Guidry et al., 2009; Lockshin \& Corsi, 2012; Bruwer \& Buller, 2013; Moulard, Babin, \& Griffin, 2015). "Old World" producers (European countries like France, Germany, Italy, Portugal, and Spain) benefit from the close tie between wine quality and place, and have strict regulations concerning production practices. On the other hand, "New World" producers (Australia, USA, South America and Eastern Europe) have not long-established history of wine production and, even if they now produce good quality wine, they employ practices forbidden by some European regulations, notably those in France, which is the world's leading producer and consumer of quality wines (Balestrini \& Gamble, 2006). 
Economic and marketing literature has extensively explored the GIs topic, given its relevance in agri-food business in terms of extent and implications (Souza Monteiro \& Ventura Lucas, 2001; Bonetti, 2004). Various studies have investigated the ability of these labels to shape consumers' perception of, and choice of, food products (e.g., Bernabéu, Díaz, Olmeda, 2010; Lentz, Holzmüller, \& Schirrmann, 2006; Orth, McGarry Wolf, \& Dodd, 2005; Menapace, Colson, Grebitus, \& Facendola, 2011). As a matter of fact, certification of origin emerged as the most effective modus to express the values associated with such an origin to consumers. This role is especially evident with reference to wine, which is closely tied to place. Indeed, the wine's place of origin is its signature to many consumers (Anna Guidry et al., 2009). In contrast, little attention has been paid to investigating the persuasion effect of the place of origin in the communication of wines.

This paper seeks to address the need for further empirical research on the opportunity to communicate the region of origin (through either pictorial or textual format, or both) in print advertising messages for wines bearing a GI label. In addressing this topic, the study has theoretical and practical implications contributing to a deeper understanding of the effectiveness of extrinsic advertising cues that leverage intangible wine values.

The remainder of the article is organized as follows. It commences by reviewing the relevant literature and stating the research hypotheses. Then, methodology and empirical results are presented. The subsequent section discusses the numerical results, highlights theoretical and managerial implications. Finally, limitations are noted and directions for further research are suggested.

\section{Literature Review}

Two streams of extant literature are reviewed in this section to gain insights into the communication of GIs labelled wine. The first stream acknowledges the influence of the place of origin on the consumers' purchasing decision process; the second stream reassumes published research papers on pictorial and textual advertising strategy.

\subsection{From the Country-of-Origin (COO) Effect to the Region-of-Origin (ROO) Effect}

A substantial body of marketing literature on $\mathrm{COO}$ from the Sixties to the present has showed that it affects consumers' perceptions and evaluations. Systematic research on this topic began with the seminal work of Schooler (1965). COO effects have been found for general products, specific categories of products, and even for certain brands. Roth and Romeo (1992) suggested that perceptions of country image differ across product categories. In the case of wine, $\mathrm{COO}$ is strongly meaningful and relevant, because it is quintessentially a product related to a territory, even if that territory is as widely defined as a country (Balestrini \& Gamble, 2006).

Studies on the effects of the place of origin and, by extension, appellations of origin represent one of the most prolific research streams in wine literature in the last decade (Lockshin \& Corsi, 2012). Typically, the wine literature classifies place of origin effects under the rubric of region and the French term "terroir" (Anna Guidry et al., 2009; Moulard et al., 2015). The wine's technical terroir refers to the topographical elements restricted to the location where the grapes were actually grown (Ballantyne, 2011; Beverland \& Luxton, 2005; Van Leeuwen \& Seguin, 2006). Its importance is clearly recognized in the public attempts to protect typical wines (Anna Guidry et al., 2009). For example, terms commonly referring to wines, such as Bordeaux, Barolo, Burgundy, Chianti, Champagne, are in reality geographical locations each associated with a type of wine.

Duhan, Kiecker, Areni and Guerrero (1999) noted that the unique characteristics of wine markets make consumers particularly sensitive to information about origin. First, since there are so many different wines and brands competing for attention in retail outlets, consumers are likely to use decision heuristics and extrinsic cues such as price or origin to inform their choice. Second, the origin of wines is often perceived (rightly or wrongly) as an indicator of quality. As a result, origin information can be an indicator of quality, because the product cannot be consumed to assess for quality prior to purchase, and the place of origin effect is likely to be very prominent in explaining wine consumers' behaviour (Elliott \& Cameron, 1994; Schaefer, 1997; Lockshin \& Hall, 2003; Balestrini \& Gamble, 2006; Moulard et al., 2015). There is a general consensus in the literature that the $\mathrm{COO}, \mathrm{ROO}$ or the technical terroir adds value to the wine and they may also support a premium price positioning. In reviewing the literature, Perrouty, d'Hauteville and Lockshin (2006) found that less experienced consumers pay more attention to wine origin cues, and it has been observed (Combris, Lecocq, \& Visser, 1997; D'Alessandro \& Pecotich, 2013) that even wine experts can be strongly influenced by the information of the region of origin when tasting a wine. Lockshin and Corsi (2012) showed that the COO or ROO are key wine choice drivers, and are even more important for higher involved buyers. Veith and Lianu (2013) demonstrated that the origin of the product influences the buying decision process, even if it is not the real origin but the perceived one. Balestrini and Gamble (2006), in their research on Chinese wine consumers, confirmed an earlier research in Western studies, which indicated that consumers tend to use extrinsic cues such as $\mathrm{COO}$, price and 
brand for wine quality assessment. Lastly, Moulard et al. (2015) suggested that wine's perceived authenticity mediates the effect of country of origin.

\subsection{Pictorial and Textual Advertising Strategy}

The effect of advertisement presentation patterns on attitudes and purchase intentions has been investigated in literature, showing that the way consumers perceive information influences their buying behaviour (e.g. Schlosser, 2003). There are three ways to advertise a geographical area in print media: through pictorial cues or textual claims or a combination of the two. Visual information in advertising is recognized as more effective, since consumers remember them more easily compared to the textual form (e.g. Mitchell, 1986; Jae, Delvecchio, \& Cowles, 2008). The explanation is based on the dual-coding theory, that distinguishes two separate mental systems, or codes, when processing information: one represents and processes language (the verbal code) and the other processes non-linguistic objects and events (the nonverbal code) (Paivio, 1986; Sadoski \& Paivio, 2004). Together, the two codes account for knowledge of language and knowledge of the world. Further studies based on the dual-coding theory restated that the image presentation mode outperforms the text-only presentation mode in terms of better recall of brand names and product images (Hong, Thong, \& Tam, 2004). Moreover, pictures facilitate the processing of messages and their meaning is connected more directly than in the case of words (Luna \& Peracchio, 2003; Paivio, 1971; Unnava \& Burnkrant, 1991; Carr, McCauley, Sperber, \& Parmelee, 1982). Another important feature of pictures is their affective valence, thus evoking a strong emotional reaction (e.g. Bradley, Greenwald, Petry, \& Lang, 1992; Lang, Greenwald, Bradley, \& Hamm, 1993; Hsee \& Rottenstreich, 2004; Lee \& Ariely, 2009; Lieberman, Gaunt, Gilbert, \& Trope, 2002). Despite these general results, some studies showed that the product category moderates the effect of pictures on consumers' memory and emotional response. For example, Kim and Lennon (2008) demonstrated the superiority of textual information for clothing products.

Further evidence indicates that the integration of picture cues with textual cues in print ads can enhance advertising impacts. The picture-text presentation mode, where an advertisement's headline merges with its pictorial content (pictorial-textual resonance), positively influences the advertisement liking, brand attitude and unaided recall of the headline (McQuarrie \& Mick, 1992, 2008). As a consequence, the coordination of words and images is a strategy that can further improve the effectiveness of advertising messages. Therefore, advertising the place of origin through a picture-text presentation should add value to the message and affirmatively impact on consumers' brand attitude and purchase intention.

A recent study by Luceri et al. (2016) investigated the effectiveness of highlighting the geographical area through either pictorial or pictorial-textual formats - in print-advertising messages for European Union Geographical Indication quality-labelled products. The paper considered two types of GIs (Melinda PDO apple and Valtellina PGI bresaola), showing a significant main effect of the region of origin presentation on purchase intention. Moreover, the presentation of the region of origin through pictorial-textual cues led to more positive responses than communication based just on pictorial cues.

That being stated, the following hypotheses are formulated:

H1. Advertising the region of origin in pictorial form has a greater effect on consumers' (a) attitude towards the advertisement and (b) purchase intention for wines bearing GI labels than the absence of references to the region of origin in the advertisement.

H2. Advertising the region of origin by combining pictorial and textual form has a greater effect on consumers' (a) attitude towards the advertisement and (b) purchase intention for wines bearing GI labels than the absence of references to the region of origin in the advertisement.

H3. Advertising the region of origin by combining pictorial and textual information has a greater effect on consumers' (a) attitude towards the advertisement and (b) purchase intention for wines bearing GI labels than the use of just pictorial cues in the advertisement.

\section{Materials and Methods}

A between-subject experimental design was used to manipulate the region of origin presentation in print advertisement (absent vs pictorial vs pictorial-textual) while measuring the participants' intention to buy the advertised GI wine (Barolo) and attitude towards the advertisement (dependent variables).

The presentation of the region of origin was manipulated using an actual print advertisement, and three stimuli advertisements were created using Photoshop software: (a) without any reference to the region of origin, either pictorial or textual; (b) with a picture of the region of origin; and (c) with a picture and textual information about the region of origin. Specifically, for (a) the advertisement used a picture of a generic natural landscape without 
any reference to the wine's region of origin; for (b) the advertisement used a picture of a landmark from the wine's region of origin (i.e. the vineyards of Fontanafredda - Piedmont); for (c) a textual reference to the region of origin was added to the picture used in (b) (i.e. the name Fontanafredda).

Three hundred undergraduate students $(48 \%$ male and $52 \%$ female; average age $24.97, \mathrm{SD}=4.07)$ from a large university in the north of Italy were involved in the experiment. After agreeing to participate, subjects were randomly assigned to one of the three experimental conditions.

The study was conducted in a laboratory setting. Each participant was given a booklet containing one full-page advertisement, a questionnaire including questions on the key dependent variables and questions about demographic profile. Participants reported their responses after viewing the advertisement.

Attitude towards the advertisement was assessed through five-item scale developed by Lee and Mason (1999). Statements were on a 5 -point Likert scale ( $1=$ completely disagree; $5=$ completely agree). These scales were "I dislike the ad", "The ad is appealing to me", "The ad is attractive to me", "The ad is interesting to me", "I think the ad is bad". A reliability analysis carried out on these five items showed a Cronbach's alpha of 0.845 . The purchase intention was measured using three 7-point scales, each anchored by $1=$ "unlikely" and $7=$ "likely". These scales were "How likely is it that you will consider this brand the next time you purchase the product?", "The next time I consider purchasing the product, I will enquire about this brand" and "The next time I buy the product, I will buy this brand" (adapted from Putrevu, 2008 by Wyllie, Carlson, \& Rosenberger, 2014). An index of purchasing intention was obtained by averaging the scores on each scale (Cronbach's $\alpha=0.838$ ).

Data analysis was performed using the IBM SPSS statistical software (release 24.0).

\section{Research Results}

One-way ANOVA and, when applicable, the Welch tests were used to test the formulated hypotheses. Specifically, when equal variances were assumed, variables were compared by means of ANOVA and Tukey post hoc tests. When equal variances were not assumed, variables were compared by means of the Welch test and Tamhane post hoc test.

The cell means and standard deviations of the variables of interest are reported in Table 1 with reference to attitude towards the advertisement and purchase intention as dependent variables.

As Table 1 shows, the mean score for attitude towards the advertisement was higher when the region of origin was present $(M=15.08$ for pictorial presentation and $M=16.47$ for pictorial-textual presentation) than when it was absent $(M=14.97)$. The ANOVA test showed a significant difference among the groups $(F(2,297)=3.828$, $p<0.05)$ and post hoc test revealed that such a difference is between "absent" and "pictorial-textual" region of origin presentation (Table 2). Therefore, H2(a) is supported, while H1(a) and H3(a) are not supported.

Table 1. Cell means and standard deviations

\begin{tabular}{lllll}
\hline \multirow{2}{*}{ Region of origin presentation } & \multicolumn{2}{l}{ Attitude towards the advertisement } & \multicolumn{2}{l}{ Purchase intention } \\
& Mean & SD & Mean & SD \\
\hline Absent & 14.97 & 4.505 & 10.07 & 4.893 \\
Pictorial & 15.08 & 4.410 & 9.88 & 4.571 \\
Pictorial-textual & 16.47 & 3.878 & 13.00 & 3.493 \\
\hline
\end{tabular}

The mean score for purchase intention was higher when the region of origin was presented in pictorial-textual form $(M=13.00)$ than when it was absent $(M=10.07)$ or presented in pictorial form $(M=9.88)$ (Table 1). The Welch test result $(F(2,194)=19.642, p<0.05)$ showed that purchase intention differed significantly among the three groups. Specifically, according to post hoc test (Table 2), the differences were two: "absent" vs "pictorial-textual" and "pictorial" vs "pictorial-textual". Therefore, purchase intention is greater when the region of origin is presented in pictorial and textual form compared to the other forms of presentation. Hence H2(b) and H3(b) are supported, while H1(b) is not supported. 
Table 2. Post hoc test

\begin{tabular}{|c|c|c|c|c|c|}
\hline & \multicolumn{2}{|c|}{ Region of origin presentation } & \multirow{2}{*}{$\begin{array}{l}\text { Mean difference } \\
-0.110\end{array}$} & \multirow{2}{*}{$\begin{array}{l}\text { Std. Error } \\
0.604\end{array}$} & \multirow{2}{*}{$\begin{array}{l}\text { p-value } \\
0.982\end{array}$} \\
\hline Attitude towards & Absent & Pictorial & & & \\
\hline the advertisement & & Pictorial-textual & -1.500 & 0.604 & $0.036^{*}$ \\
\hline \multirow[t]{4}{*}{ (Tukey HSD) } & Pictorial & Absent & 0.110 & 0.604 & 0.982 \\
\hline & & Pictorial-textual & -1.390 & 0.604 & 0.057 \\
\hline & Pictorial-textual & Absent & 1.500 & 0.604 & $0.036^{*}$ \\
\hline & & Pictorial & 1.390 & 0.604 & 0.057 \\
\hline \multirow{6}{*}{$\begin{array}{l}\text { Purchase intention } \\
\text { (Tamhane) }\end{array}$} & Absent & Pictorial & 0.190 & 0.670 & 0.989 \\
\hline & & Pictorial-textual & -2.930 & 0.601 & $0.000 *$ \\
\hline & Pictorial & Absent & -0.190 & 0.670 & 0.989 \\
\hline & & Pictorial-textual & -3.120 & 0.575 & $0.000 *$ \\
\hline & Pictorial-textual & Absent & 2.930 & 0.601 & $0.000 *$ \\
\hline & & Pictorial & 3.120 & 0.575 & $0.000 *$ \\
\hline
\end{tabular}

* The mean difference is significant at the 0.05 level.

\section{Discussion}

Wine is the most differentiated of all agriculturally-based consumer products, with long traditions that make the place of origin particularly significant in the consumers' buying decision process. The area of production presents positioning opportunities, thus creating a sustainable competitive advantage. The EU GI schema captures this connection: the role of GIs is to make wines from a region recognisable for a particular quality and as unique to that region (Moran, 1993). As a result, place name and production become integrated (Henchion \& McIntyre, 2000), with the opportunity to highlight the geographical area as a source of differentiation in the communication of GI wines. To this end, a variety of cues can be exploited: specific landscapes, cultural traditions, historic monuments etc. Nevertheless, the ability of the place of origin to increase consumers' purchase intention has not been systematically tested in an advertising context with reference to wine. The aim of the present study was to fill this gap and to deepen the knowledge on the communication effectiveness of the region of origin in print advertising messages for wine bearing a GI label. Overall, it provides empirical support to the appropriateness of highlighting the geographical area by combining textual - pictorial cues to induce a positive attitude towards the advertisement and purchase intention in consumers.

The extrinsic advertising cues that leverage intangible product values - that is to say, the region of origin - are found to create value. As a matter of fact, the geographical area exerts a more favourable influence on consumers' purchase intention when it is conveyed in pictorial-textual format rather than just in a pictorial one or when there is no reference to it in the advertisement. The presentation of the region of origin combining pictorial and textual cues also leads to a more positive effect on consumers' attitude towards the advertisement than when there is no reference to it in the advertisement. Last but not least, communicating the region of origin through pictorial cues does not lead to more favourable responses than when there is no reference to it in the advertisement.

The study has implications for both academics and practitioners.

For marketing researchers, by addressing a topic thus far unexplored in the wine literature, it contributes to a deeper understanding of the persuasive effect of the place of origin in a print advertising context. Key implications are the validation of the pictorial-textual superiority effect, which has been speculated about in previous advertising research (e.g. McQuarie \& Mick, 1992; 2008) and verified by Luceri et al. (2016) with reference to PDO apples and PGI bresaola. Specifically, the persuasion effect of the geographical area is more effective when pictorial cues are combined with textual claims (versus the mere pictorial format). Differently from what was hypothesized, the presentation of the region of origin through pictorial cues does not lead to more positive responses than when there is no reference to it in the advertisement. Such a finding is in contrast with that of Luceri et al. (2016), indicating that in the context of wine highlighting the geographical area through pictorial format is insufficient.

For marketing professionals, the study provides practical insights to optimize the place of origin effect in the wine sector advertisements. First, presenting the geographical area is important, as it affects both the attitude towards the advertisement and the purchase intention. Second, the study provides empirical support to the importance of the pictorial-textual coordination strategy in print media advertisements. Finally, establishing 
associations with the region of origin may be a useful communication strategy both in the domestic market and in the export markets for producers. Furthermore, regional image can be better exploited bundling together several GI labelled products of that region (i.e. wine, cheese, meat, fruit). Obviously, they must share the same values of their region of origin and these values have to be symbolized by the same specific landmark.

\section{Limitations and Future Research Recommendations}

This study is subject to limitations that provide avenues for future research.

First, it was considered a well-known PDO wine (Barolo) with a strong link with the region of origin (Piedmont). Therefore, other types of typical wine (for example PDO vs PGI; well-known typical wine vs less known typical wine) should be considered.

Second, just one manipulation was used in the experimental design. The message might be conveyed in other ways, given the variety of possibilities for creative advertising and the variety of landmarks that may exist in the region of origin. Future researchers are thus encouraged to employ alternative methods of execution (for pictorial and pictorial-textual cues) to further validate the persuasive results here reported.

Third, this study considered just print advertising. Future research may involve other communication media, in light of the rising importance of new media (e.g. social networks, mobile apps). This is useful to have a general overview of the effectiveness of communicating the region of origin to influence attitude towards the advertisement and purchase intention.

Fourth, this research is subject to potential sample composition issues, as it is focused on a student target. The use of a convenience sample may have compromised its representativeness given that students may care mostly about price and not so much about the origin of the wine. Therefore, further studies are recommended to extend the investigation to a larger sample that is representative of the national population.

Finally, the study ignores the individual knowledge factor that might provide insights to further understand the conditions that qualify the persuasion effect of the geographical area on consumers with different levels of experience of wine bearing GI labels. Future research is encouraged to integrate variables as the consumers' familiarity with the region, the product and GI labels, as they are highly significant variables in the wine sector. As a matter of fact, there is evidence that the place of origin effect is stronger for purchasers with a better knowledge of GI schema and prior awareness of regional products bearing these labels (e.g., Chamorro et al., 2015).

\section{References}

Anna Guidry, J., Babin, B. J., Graziano, W. G., \& Joel Schneider, W. (2009). Pride and prejudice in the evaluation of wine?. International Journal of Wine Business Research, 21(4), 298-311. https://doi.org/10.1108/17511060911004888

Balestrini, P., \& Gamble, P. (2006). Country-of-origin effects on Chinese wine consumers. British Food Journal, 108(5), 396-412. https://doi.org/10.1108/00070700610661367

Ballantyne, D. (2011). Sustaining the promise of terroir: the case of the Central Otago Wine Region. In 6th Academy of Wine Business Research Conference, 9-11.

Bernabéu, R., Díaz, M., \& Olmeda, M. (2010). Origin vs organic in Manchego cheese: which is more important?. British Food Journal, 112(8), 887-901. https://doi.org/10.1108/00070701011067488

Beverland, M., \& Luxton, S. (2005). Managing integrated marketing communication (IMC) through strategic decoupling: How luxury wine firms retain brand leadership while appearing to be wedded to the past. Journal of Advertising, 34(4), 103-116. https://doi.org/10.1080/00913367.2005.10639207

Bonetti, E. (2004). The effectiveness of meta-brands in the typical product industry: mozzarella cheese. British Food Journal, 106(10-11), 746-66. https://doi.org/10.1108/00070700410561360

Boyazoglu, J. (1999). Genetically Modified Organisms (GMOs) and Specific Quality Products (PDO, PGI, etc.), with special Reference to Europe and the Mediterranean Basin. Medit, 10(4), 4-7.

Bradley, M. M., Greenwald, M. K., Petry, M. C., \& Lang, P. J. (1992). Remembering Pictures: Pleasure and Arousal in Memory. Journal of Experimental Psychology: Learning, Memory, and Cognition, 18(2), 379-390. http://dx.doi.org/10.1037/0278-7393.18.2.379

Bruwer, J., \& Buller, C. (2013). Product involvement, brand loyalty, and country-of-origin brand preferences of Japanese wine consumers. Journal of Wine Research, 24(1), 38-58. https://doi.org/10.1080/09571264.2012.717221 
Carr, T. H., McCauley, C., Sperber, R. D., \& Parmelee, C. M. (1982). Words, Pictures, and Priming: On Semantic Activation, Conscious Identification, and the Automaticity of Information Processing. Journal of Experimental Psychology: Human Perception and Performance, 8(6), 757-777. http://dx.doi.org/10.1037/0096-1523.8.6.757

Chamorro, A., Rubio, S., \& Miranda, F. J. (2015). The region-of-origin (ROO) effect on purchasing preferences: the case of a multiregional designation of origin. British Food Journal, 117(2), 820-839. https://doi.org/10.1108/BFJ-03-2014-0112

Combris, P., Lecocq, S., \& Visser, M. (1997). Estimation of a hedonic price equation for Bordeaux wine: does quality matter? The Economic Journal, 107(441), 390-402. https://doi.org/10.1111/j.0013-0133.1997.165.x

D’Alessandro, S., \& Pecotich, A. (2013). Evaluation of wine by expert and novice consumers in the presence of variations in quality, brand and country of origin cues. Food Quality and Preference, 28(1), 287-303. https://doi.org/10.1016/j.foodqual.2012.10.002

Dimara, E., \& Skuras, D. (2003). Consumer evaluations of product certification, geographic association and traceability in Greece. European journal of marketing, 37(5-6), 690-705. https://doi.org/10.1108/03090560310465099

Duhan, D. F., Kiecker, P. L., Areni, C. S., \& Guerrero, C. (1999). Origin information and retail sales of wine. International Journal of Wine Marketing, 11(3), 44-57. https://doi.org/10.1108/eb008699

Elliott, G. R., \& Cameron, R. C. (1994). Consumer perception of product quality and the country-of-origin effect. Journal of international Marketing, 49-62.

Gilg, A., \& Battershill, M. (1998). Quality farm food in Europe: a possible alternative to the industrialised food market and to current agri-environmental policies: lessons from France. Food Policy, 23(1), 25-40. https://doi.org/10.1016/S0306-9192(98)00020-7

Henchion, M., \& McIntyre, B. (2000). Regional imagery and quality products: the Irish experience. British Food Journal, 102(8), 630-644. https://doi.org/10.1108/00070700010348514

Hong, W., Thong, J. Y. L., \& Tam, K. Y. (2004). Designing product listing pages on e-commerce websites: an examination of presentation mode and information format. International Journal of Human-Computer Studies, 61, 481-503. https://doi.org/10.1016/j.ijhcs.2004.01.006

Hsee, C. K., \& Rottenstreich, Y. (2004). Music, Pandas, and Muggers: On the Affective Psychology of Value. Journal of Experimental Psychology: General, 133(1), 23-30. http://dx.doi.org/10.1037/0096-3445.133.1.23

Ilbery, B., \& Kneafsey, M. (1998). Product and place: promoting quality products and services in the lagging rural regions of the European Union. European Urban and Regional Studies, 5(4), 329-341. http://dx.doi.org/10.1177/096977649800500404

Jae, H., Delvecchio, D. S., \& Cowles, D. (2008). Picture-Text Incongruency in Print Advertisements among Low-and High-Literacy Consumers. Journal of Consumer Affairs, 42(3), 439-451. http://dx.doi.org/10.1111/j.1745-6606.2008.00117.x

Kim, M., \& Lennon, S. (2008). The effects of visual and verbal information on attitudes and purchase intentions in internet shopping. Psychology and Marketing, 25(2), 146-178. http://dx.doi.org/10.1002/mar.20204

Kim, R. (2008). Japanese consumers' use of extrinsic and intrinsic cues to mitigate risky food choices. International Journal of Consumer Studies, 32(1), 49-58. http://dx.doi.org/ $10.1111 / \mathrm{j} .1470-6431.2007 .00636 . \mathrm{x}$

Lang, P.J., Greenwald, M.K., Bradley, M.M., \& Hamm, A.O. (1993). Looking at Pictures: Affective, Facial, Visceral, and Behavioral Reactions. Psychophysiology, 30(3), 261-273. http://dx.doi.org/10.1111/j.1469-8986.1993.tb03352.x

Lee, L., Amir, O., \& Ariely, D. (2009). In Search of Homo Economicus: Cognitive Noise and the Role of Emotion in Preference Consistency. Journal of Consumer Research, 36(2), 173-187. https://doi.org/10.1086/597160

Lee, Y. H., \& Mason, C. (1999). Responses to information incongruency in advertising: The role of expectancy, relevancy, and humor. Journal of Consumer Research, 26(2), 156-169. https://doi.org/10.1086/209557

Lentz, P., Holzmüller, H.H., \& Schirrmann, E. (2006). City-of-origin effects in the German beer market: 
transferring an international construct to a local context. Advances in International Marketing, 17, 251-274. https://doi.org/10.1016/S1474-7979\%2806\%2917009-X

Lieberman, M.D., Gaunt, R., Gilbert, D.T., \& Trope, Y. (2002). Reflexion and reflection: A social cognitive neuroscience approach to attributional inference. Advances in experimental social psychology, 34, 199-249. https://doi.org/10.1016/S0065-2601(02)80006-5

Lockshin, L., \& Corsi, A. M. (2012). Consumer behaviour for wine 2.0: A review since 2003 and future directions. Wine Economics and Policy, 1(1), 2-23. https://doi.org/10.1016/j.wep.2012.11.003

Lockshin, L., \& Hall, J. (2003). Consumer purchasing behaviour for wine: What we know and where we are going. Doctoral dissertation, University of South Australia, Wine Marketing Research Group.

Luceri, B., Latusi, S., \& Zerbini, C. (2016). Product versus region of origin: which wins in consumer persuasion? British Food Journal, 118(9), 2157-2170. https://doi.org/10.1108/BFJ-01-2016-0035

Luna, D., \& Perrachio, L.A. (2003). Visual and Linguistic Processing of Ads by Bilingual Consumers. In Scott, L.M., \& Batra, R. (Eds.), Persuasive imagery: A consumer response perspective, NJ: Erlbaum, Routledge, $153-175$

McQuarrie, E. F., \& Mick, D. G. (1992). On resonance: A critical pluralistic inquiry into advertising rhetoric. Journal of Consumer Research, 19(2), 180-197. https://doi.org/10.1086/209295

McQuarrie, E. F., \& Mick, D. G. (2008). A laboratory study of the effect of verbal rhetoric versus repetition when consumers are not directed to process advertising. International Journal of Advertising, 28(2), 287-312. https://doi.org/10.2501/S0265048709200576

Menapace, L., Colson, G., Grebitus, C., \& Facendola, M. (2011). Consumers' preferences for geographical origin labels: evidence from the Canadian olive oil market. European Review of Agricultural Economics, 38(2), 193-212. https://doi.org/10.1093/erae/jbq051

Mitchell, A. (1986). The effect of verbal and visual components of advertisements on brand attitudes and attitude toward the advertisement. Journal of Consumer Research, 13(1), 12-24. https://doi.org/10.1086/209044

Moran, W. (1993). Rural space as intellectual property. Political Geography, 1(3), 263-277. https://doi.org/10.1016/0962-6298(93)90057-E

Mørkbak, M.R., Christensen, T., \& Gyrd-Hansen, D. (2010). Consumer preferences for safety characteristics in pork. British Food Journal, 112(7), 775-791. https://doi.org/10.1108/00070701011058299

Moulard, J., Babin, B.J., \& Griffin, M. (2015). How aspects of a wine's place affect consumers' authenticity perceptions and purchase intentions: The role of country of origin and technical terroir. International Journal of Wine Business Research, 27(1), 61-78. https://doi.org/10.1108/IJWBR-01-2014-0002

Orth, U. R., McGarry Wolf, M., \& Dodd, T. H. (2005). Dimensions of wine region equity and their impact on consumer preferences. Journal of Product \& Brand Management, 14(2), 88-97. https://doi.org/10.1108/10610420510592563

Paivio, A. (ed.) (1971). Imagery and Verbal Processes. New York: Holt, Rinehart, \& Winston.

Paivio, A. (ed.) (1986). Mental Representations: A Dual Coding Approach. Oxford University Press, New York.

Perrouty, J. P., d'Hauteville, F., \& Lockshin, L. (2006). The influence of wine attributes on region of origin equity: An analysis of the moderating effect of consumer's perceived expertise. Agribusiness, 22(3), 323-341. https://doi.org/10.1002/agr.20089

Putrevu, S. (2008). Consumer responses toward sexual and nonsexual appeals: The influence of involvement, need for cognition (NFC), and gender. Journal of Advertising, 37(2), 57-70. https://doi.org/10.2753/JOA0091-3367370205

Roth, M.S., \& Romeo, J.B. (1992). Matching product category and country image perceptions: A framework for managing country-of-origin effects. Journal of international business studies, 23(3), 477-497.

Sadoski, M., \& Paivio, A. (2004). A dual coding theoretical model of reading. In Ruddell, R.B., \& Unrau, N.J. (Eds.), Theoretical Models and Processes of Reading (5th ed.). International Reading Association, Newark, DE, 1329-1362.

Sanz-Cañada, J., \& Muchnik, J. (2011). Ancrage et identité territoriale des systèmes agroalimentaires localizes. Introduction au dossier. Economie Rurale, 322, 4. 
Schaefer, A. (1997). Consumer knowledge and country of origin effects. European Journal of Marketing, 31(1), 56-72. https://doi.org/10.1108/03090569710157034

Schlosser, A.E. (2003). Computers as situational cues: implications for consumer product cognitions and $\begin{array}{lllll}\text { attitudes. Journal of } & \text { Consumer } & \text { Psychology, } & 13(1), & 103-112 .\end{array}$ https://doi.org/10.1207/S15327663JCP13-1\&2_09

Schooler, R.D. (1965). Product bias in the Central American Common Market. Journal of Marketing Research, 2(4), 394-397. https://doi.org/10.2307/3149486

Souza Monteiro, D., \& Ventura Lucas, M.R. (2001). Conjoint measurement of preferences for traditional cheeses in Lisbon. British Food Journal, 103(6), 414-424. https://doi.org/10.1108/00070700110400406

Türkekul, B., Günden, C., Abay C., \& Miran, B. (2010). Competitiveness of Mediterranean countries in the olive oil market. New Medit, 9(1), 41-46.

Unnava, H.R., \& Burnkrant, R.E. (1991). An Imagery-Processing View of the Role of Pictures in Print Advertise-ments. Journal of Marketing Research, 28(2), 226-231. https://doi.org/10.2307/3172811

Van Ittersum, K., Candel, M. J. J. M., \& Meulenberg, M. T. G. (2003). The influence of the image of a product's region of origin on the product evaluation. Journal of Business Research, 56(3), 215-226. https://doi.org/10.1016/S0148-2963(01)00223-5

Van Leeuwen, C., \& Seguin, G. (2006). The concept of terroir in viticulture. Journal of Wine Research, 17(1), 1-10. https://doi.org/10.1080/09571260600633135

Veith, C., \& Lianu, C. (2013). Origin of the product and the buying decision. Theoretical \& Applied Economics, 20(11), 147-164.

Wyllie, J., Carlson, J., \& Rosenberger III, P. J. (2014). Examining the influence of different levels of sexual-stimuli intensity by gender on advertising effectiveness. Journal of Marketing Management, 30(7-8), 697-718. https://doi.org/10.1080/0267257X.2013.838988

\section{Copyrights}

Copyright for this article is retained by the author(s), with first publication rights granted to the journal.

This is an open-access article distributed under the terms and conditions of the Creative Commons Attribution license (http://creativecommons.org/licenses/by/4.0/). 